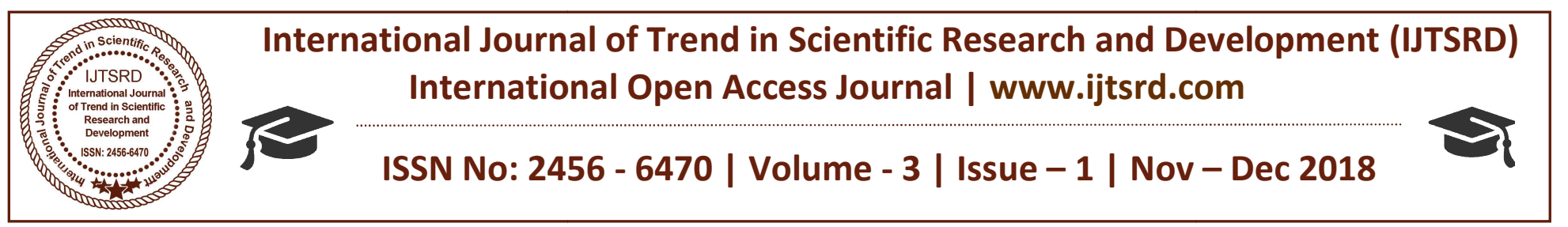

\title{
A Study of the Plight of Transgenders - A Life No Less Than A Living Hell
}

\author{
Dr. Ashwani Rana \\ Associate Professor and Research Guide, \\ CT University, Ludhiana, Punjab, India
}

\author{
Ms. Ritika Rana \\ PGT History \& Hindi \\ Bawa Lalvani Public School, Kapurthala, Punjab
}

\begin{abstract}
This world is extremely beautiful. The almighty has bedecked it very cautiously and meticulously with varied shades, colours, species and kinds. There exists a third gender in this beautiful world that is either altogether alienated or detested. Society does not accept them. Fathers consider it to be ai defamation in society. Mothers reluctantly let such go out of their own home. They are not allowed to get education, there are no job opportunities for them, and they are not accepted whole-heartedly. They are compelled to work as sex workers or to beg at public places and in public transportations. Such children have female elements in them. They would feel like playing with dolls and the like toys, but the parents would not allow them. Their playing with other children is a big issue, life at school is a big question mark, they would be expelled from their home - identity crisis begging in trains and buses - they take birth like other children, they are like other human beings - gender is secondary - it must be understood. Many of them feel like they should be given identity cards and fundamental rights like other human beings.
\end{abstract}

KEY WORDS: Transgender, Hijra, Kinnar, Shagird, prostitution, biological

\section{INTRODUCTION}

The history is replete with ample examples of the prevalence of transgender in every era so far. They were the courtesans and given a special place, designations and rankings in the royal courts of the kings. The kings trusted them more than males/females. The eunuchs were prominently working as personal assistants or one of the most significant ministers of the kings that time. The society would honour them in various ways by addressing them with respectable titles. Their prevalence can be figured out in almost every community across the world.

\section{CATEGORIES OF TRANSGENDERS}

There are different categories of transgenders. People have generalised them to be neutral or the ones who do not have any reproductive organs, but it is not so. The transgenders can be - a biological man with female elements in him and a lot of effeminate behaviour. He is actually a male, but loves to live like, look like, dress up like a female. Then there is second category of biological females who are possessed with male elements in them and want to be like males. Thus, the transgenders are neither completely a male nor completely a female. They consider themselves to be someone in a wrong body, a misfit; and, so, want to lead the life of another sex. The governments of various countries have labelled them to be - Third gender. The third type of transgenders is of those who are naturally born to be neutral, that is, the ones who do not have any reproductive organ - a complete eunuch or kinnar.

\section{DEROGATORY NAMES GIVEN TO TRANSGENDERS}

The society does not treat these transgenders well. They are given derogatory names like - 'Hijra', 'Chhakka', 'Mamu', 'Khusra', 'Adhoora' etc. which has to be looked into seriously. They too are human beings first and then a gender, but nobody pays that type of respect to them or else treat them to be a human being. The transgenders suffer from this evil of alienation. They are shunted out of their homes and disowned in the name of the reputation and respectable image of their clan. They are considered to be a social stigma and hence no one is ready to 
accept or provide shelter to them. At home, they are maltreated by the male members like their father or brother(s), in society, the neighbouring children get on their nerves and make it a living hell for them and thus make it very difficult for them to survive. They consistently feel choked and isolated.

\section{PATRIARCHAL RULES OF SOCIETY}

In a patriarchal society like India and Pakistan, the transgenders suffer a lot at the hands of their own kith and kin. The fathers are not ready to allow them to stay back at home with rest of the family. Certain conditions are levied on them that they must behave like other normal members of the family, failing which, they are beaten severely. There are number of examples which can be easily found and quoted here when the transgenders (a so-called biological male child) used cosmetics, tried to grow nails or hair, dressed up like a female - the male member of the family -either brother or the father beat them severely . Finally, when the males failed to bring these third gender human beings on a right track they simply threw them out of their houses and disowned them.

\section{NEVER GIVE UP}

Life is difficult but not impossible; so is the case with these deserted transgenders. Many of them fall an easy prey to prostitution for their survival. They decide places - public places and also, they decide late hours of night - where they stand and offer themselves to be sold for a couple of hours or a night and this way they make their living possible. But this bad profession of prostitution is also not that easy. They have to undergo variegated surgeries to look like females - may it be for enhancing the growth of their breasts, facial surgery or genital organ's surgery. They need to take various medicines for hormonal changes. These surgeries and medicines have to be taken regularly or else they may fail to attract their customers. To our utter surprise, these transgenders are not provided with proper medical facilities. The doctors as well as the other patients in a hospital are biased. The females don't allow them admitted in female wards and likewise males do not let them admitted in male wards nor do these two supreme genders let this third gender use their washrooms which is truly a shameful thing for humanity. This way, one of them, with a little knowledge of medicines, without any formal doctoral degree - cures them!! Yes!! That's right - they have to...there is no other way.
In Pakistan, the transgenders are titles as 'Khwajasirah' - they are respectfully named as the divine maid-servants of the Almighty. The things are not altogether good in Pakistan as well. The transgenders are called 'Hijras' - which is considered to be a derogatory name, but looking at the depth of the meaning of this word, one can make out that 'Hijr' is a span during which the Muslim begin their divine journey and thus, the word 'Hijra' means a journey towards the unknown - the Almighty. Since times immemorial, the transgenders have been given quite an important place in both the countries - India as well as Pakistan, during occasions like marriage of one's son, birth of a son, and some other ceremonial occasions where the kinnars would be the invited in order to seek their blessings, but with the advancement of science and technology and also with the latest inventions of music systems, a drastic change in societal set up has taken place due to which the kinnars have been deprived of their special importance. These days they are convinced to beg at traffic signals, in buses and in trains.

\section{BENCHMARKS SET BY TRANSGENDERS}

There is a brighter side to this third category as well. The ones, who were not disowned by their parents, whose mothers took a strong stand for them, who were blessed with a silver spoon in their mouth - have set certain benchmarks. These kids were given the opportunity to get basic as well as higher education. Some of them are enjoying high-profile designations and they do not need any kind of formal introduction. To name a few - Lakshmi Narayan Tripathi - who is the first ever transgender to be the Acharaya of Hindu Akhara, a renowned celebrity as she has participated in various reality shows, a social activist - who is consistently working for the upliftment and welfare of her own community. She has a huge number of national as well as international awards, honours and accolades to her credit. She is a magnanimous classical dance and trainer, a remarkable author and one of her hot selling book is - 'Me Lakshmi, Me Hijra', in which some personal and general experiences of transgenders have been shared. She has been interviewed for a number of times at various studios of various countries.

The second name is of Gauri Sawant - a diligent social activist, commonly known as 'Amma', who is sheltering five girls and providing them higher education and a better life under her own safe wings. 
She is truly an 'Amma' or 'Aayee' in Marathi. She is working as an awareness activist who is always on her toes to lend a helping hand to anyone who is undergoing the tyrannies of the society. Gauri is a wonderful human being, a magical RJ, an expert orator and a determined social-worker. She provides food and shelter not only to the disowned transgenders but also to the thrown foetus of female children in the garbage boxes. She has adopted five girls under the aforementioned circumstances and is providing them motherly love.

There are so many other examples like Lakshmi and Gauri, who have set examples - the one which deserves to be mentioned here, is a kinnar in Pakistan who was thrown out of the house after a severe beating on the grounds that being a biological male, he was behaving like a female and even after number of reminders and warnings by brothers and father didn't mend his ways. This transgender (Aashee) took shelter in a hotel where he used to dance putting on dress of a girl and thus, made livelihood. After fifteen years his mother fell seriously sick and his father, after a great struggle, located him and implored to come back home. He visited home just for the sake of mother, brought her along with him, set up a boutique and started looking after his mother. Now this transgender is in his sixties and he took care of his mother till her last breath. In his boutique, he has given employment to various other transgenders to help them financially and hence to stay away from prostitution for their livelihood.

Another example to quote, is, of Sana - popularly known as Sana Jaan - a very much sought after transgender - who used to dance in the marriage parties to earn livelihood. Sana had tie-ups with various orchestra groups. As and when these orchestra groups would get an invitation for a function - Sana would accompany them. Her dance would be highly appreciated. The men would love to dance with her. Sana didn't want to be a sex-worker that is why she opted dancing for a profession. On odd days, she would dance in hotels or pubs. Once she performed in a wedding party. There was a group of boys, badly drunk, who started dancing with her and then took her forcibly along with them and sexually assaulted her much against her wishes. She confessed that she never wanted to do such a lowly thing - but, according to her, it was her femininity that was molested and destroyed. Somehow, God took pity on her as well as other transgenders. The government decided to provide identity cards, right to vote and clerical jobs to transgenders - those who were literate. Sana and her five friends got a clerical job of recovery of premium in an insurance company. Although the government offered a meagre salary, with which it was not easy to make the things pleasing, still, it was a better option than dancing, begging or prostitution.

If we glance at the pages of History, we come across some exemplary transgenders who did a wonderful job - to name such a transgender here - Shabnam Mausi's name can be mentioned without any second opinion. She was a very cooperative and cordial human being with the warmth of a philanthropist in her basic nature. She never wanted to be a politician, but she was dragged into politics. There was a very strong candidate in the opposite party who was in power for so many years. But due to goodness of Shabnam Mausi, she won the elections in the state of Madhya Pradesh as a member of Madhya Pradesh State Legislative assembly from 1998 to 2003.

In India also Supreme court has given a green signal to transgenders with the privilege of an identity card, right to vote and right to work or else run their own business. The mentality of a layman has not changed as yet - it is still the same. They would pity a transgender begging at a signal or in a train, but would never offer a job to them. One such transgender - Dr. Rumana is working for the welfare of her community. She is running a beauty parlour and has offered employment to various transgenders. She is also fighting for the equal rights and a respectable place for transgenders in our society. There is another doctorate transgender professor's example working at DU, New Delhi, and a college principal at Haryana state college.

\section{CHALLENGES THAT A TRANSGENDER HAS TO FACE}

Life as a transgender in India as well as in Pakistan is not an easy task. It is a life of neglect, isolation, loneliness, humiliation, sexual harassment and exploitation. The kinnars have to seek shelter of a 'guru', who is their all in all - parents, siblings, relatives, friends etc. A guru takes responsibility of a 'shagird' on monetary grounds - that is, the guru will take care of medical, emotional and financial security of the shagird - in return, the shagird will earn and hand over a major part of earning to the guru. The Gurus decide the amount of money to be paid per month failing which the shagird has to bear the 
penalty money - an additional burden. To earn the share of the guru and for personal upkeep, the kinnar is compelled to beg or sell her body. There is an auspicious day when all the kinnars marry ARAVAN - mythologically son of Arjun and a Naagkanya. The kinnars marry Aravan and the next day Aravan dies and the kinnars pose to be widows. They get ready like a bride on their wedding with their divine God Aravan and the next day they all believe that Aravan has died - so, they break their bangles and dismantle their jewellery one by one just like a widow does, wipe out the signs of marriage and then on, they start leading the life of a virgin - a deity.

\section{HISTORY OF ARAVAN}

According to one of the sections in Hindu epic Mahabharta, when Arjun was cursed by a sage and had to spend a life of a kinnar for a year, he went for his agyaatvaas in Naaglok and began to teach music to the princess. The curse period ended and he regained his manly looks and body. The princess fell in love with him and both got married. They were blkessed with a male-child named ARAVAN. By this time Arjun was reminded of his family and brothers. He left his wife and son and joined his family. At the time of Great War of Mahabharat, Aravan came to join his father in order to support him in the war. Lord Krishna said that for a Hawan Yajan they need to sacrifice a prince with pious mind in order to win over the enemy. Aravan offered himself for this sacrifice but he also disclosed his latent desire that he wanted to get married before dying. So, Lord Krishna acquired 'Mohini Roop' and married Aravan. The next day Aravan was sacrificed. Lord Krishna - being a male - in his incarnation of Mohini - wept bitterly at the death of Aravan as if truly a woman would have lost her husband and turned a widow - since that day, all the kinnars gather together to take part in the Koovagam festival by re-enacting the marriage of Aravan and Mohini. The Aravaniss (kinnars) participate in similar Kuttantavar festivals, of smaller scale, in other villages like Tevanampattanam, Tiruvetkalam, Adivarahanattum -5 miles $(8 \mathrm{~km})$ north-west of Chidambaram - and Kotthatai (all in Tamil Nadu) and also in Pillaiyarkuppam, in Puducherry and there is a group marriage of all those kinnars with their ardently worshipped God - cum husband - Aravan.

On the contrary, in Pakistan, all the kinnars, who are termed to be 'Khwajasirah', they consider 'Allah' to be their guide, their mentor, their path finder and hence, dedicate their lives in HIS service.

\section{THE OTHER SIDE OF THE PICTURE}

There is a darker side of our society to this neglected section of social-set-up. The priests, pujaris, mullahs and all religious gurus, who strongly criticise the transgenders with bitter words, that if a person is a biological male but has elements of a female - should not go against nature, rather respect the will of the God and behave like a male only. And the one who is biological female. Should behave like a female only. To everyone's utter surprise, if a survey on transgender prostitution is conducted, one will be highly shocked to find the results, to learn that out of their regular customers, the most frequently visiting customers are these so-called religious gurus - may he be a priest/pastor of a church, pujari of a temple or a mullah of a mosque.

\section{CONCLUSION}

Here, the society has to take the onus to help this third gender section, who are also human beings, they are also made up of the same stuff, but they are little special, unique. They must be treated with respect, love and sympathy. They must be given an equal place in society instead of ignoring them or belittling them by deserting or disowning. The parents of such children must show guts to take their responsibility as they do for other children, provide them with all those facilities and comforts which other children in the family are provided with. They must be educated and trained to be self-dependent instead of throwing them out of the house for begging or being exploited.

A human being is the one who has a feeling of sympathy, pity, generosity, tenderness and care for other human beings. One can never even think of behaving this way even with their pet animals as many of the transgenders have been treated by their own parents and siblings only. We all must feel that they too have feelings, they too need a family, a company, a friend to celebrate and to live happily. The parents must keep aside their fake reputation and social status and must stand by such children instead of throwing them out of their homes and out of their lives. There are some examples of parents who took stand with such children and supported them but the number of such parents is very less. Everyone - not only the parents, but their siblings and society - all have to change their mind-set and support these 
children to help them get their fundamental rights that they truly deserve.

\section{REFERENCES}

1. Ashraf, G. (2010, January 18). Debating the Third Gender. Retrieved from http://www.susans.org/forums/index.php?topic $=7$ 1078.0

2. Beemyn, Genny and Susan Rankin. The Lives of Transgender People. New York: Columbia University Press, 2011.

3. Chakrapani, Venkatesan. (December, 2010). Hijras/Transgender woman in India: HIV, Human Rights and Social Exclusion. United Nations Development Programme (UNDP), India

4. Coin a term for calling transgenders times of India. India times. Com

5. Doan, Petra. "The Tyranny of Gendered Spaces Reflections From Beyond the Gender Dichotomy." Gender, Place and Culture 17.5 (2010): 635-654.

6. GLAAD Media Reference Guide (2011) Transgender Issues, GLAAD.

7. Kalra G (2012) Hijras: the unique transgender culture of India. International Journal of Culture and Mental Health 5: 121-126.

8. Levitt, H. M., \& Ippolito, M. R. (2014). Being Transgender: The experience of transgender identity development. Journal of homosexuality, 1727-1758.

9. Nagarajan R (2014) First count of third gender in census: 4.9 lakh. The Times of India, Delhi.
10. Namaste, Viviane. Invisible Lives: The Erasure of Transsexual and Transgendered People. Chicago: University of Chicago Press, 2000.

11. Nanda S (1986) The Hijras of India: Journal of Homosexuality 11: 35-54.

12. Nanda, S. (1999). Neither Man nor Woman: The Hijras of India. Belmont, CA: Wadsworth.

13. O S (2009) Transgenderism: Facts and fictions. Indian J Psychiatry 51: 73-75.

14. Roen, Katrina. "Transgender Theory and Embodiment: The Risk of Racial Marginalisation." Journal of Gender Studies 10.3. (2001): 253-263.

15. Saxena, P. (2011). Life of a Eunuch. Santa Publishing House.

16. Sennott, S., \& Smith, T. (2011). Translating the sex and gender continuums in mental health: A transfeminist approach to client and clinician fears. Journal of Gay \& lesbian Mental Health, $15(2), 218-234$

17. Singh, A. A., Hays, D. G., \& Watson, L. S. (2011). Strength in the face of adversity: Resilience strategies of transgender individuals. Journal of Counselling and development: JCD, 20.

18. Slamah, K. (2005). The Struggle to be ourselves, neither Men nor Women: Mak Nyahs in Malaysia.

19. Victims or Villains: Examining Ten Years of Transgender Images on T.V- www.glaad.org.

20. Vidya, Living Smile. I Am Vidya. India: Rupa Publications, 2013. Print.

21. www.quora.com 